\title{
MAGMATIC ARC AND ASSOCIATED GOLD, COPPER, SILVER, AND BARITE DEPOSITS IN THE STATE OF GOIÁS, CENTRAL BRAZIL: CHARACTERISTICS AND SPECULATIONS
}

\author{
RAUL MINAS KUYUMJIAN ${ }^{1}$
}

\begin{abstract}
In the western portion of the State of Goiás, Central Brazil, base-metal deposits typical of volcanic-plutonic arcs occur. Upto-date studies suggest that porphyry $\mathrm{Cu}-\mathrm{Au}$, (volcanogenic ?) hydrothermal exhalative $\mathrm{Cu}-\mathrm{Au}$ and stratiform, submarine exhalative $\mathrm{Au}-\mathrm{Ag}$-Ba are present. Although restricted, the present state of knowledge on the geology and mineralizations of the magmatic arc indicates potential resources for metallic mineral deposits in the Brasília Belt.
\end{abstract}

Keywords: mineral deposits, magmatic arc, Goiás, Central Brazil.

INTRODUCTION The Magmatic Arc of western Goiás is located within the Brasilia Belt, a complex fold-and thrust belt of more than one episode of deformation during the Brasiliano orogeny, in the central part of the Tocantins Province. The Tocantins Province is a large Neoproterozoic orogen in Central Brazil (Richardson et al. 1988 , Pimentel et al. 1997, 1998). The magmatic arc is prevalently formed by Neoproterozoic island-arc terranes consisting of tonalitic to granodioritic orthogneisses, volcanic-sedimentary associations and late- to post-orogenic intrusions of granites and gabbros. (Pimentel et al. 1999). The terrane is strongly fractured and faulted and mineralizations are confined to fault-related fluid channelways (Araújo Filho and Kuyumjian 1996). This paper reviews past and new data for mineral deposits of the magmatic arc, and emphasizes the potentiality for metallic minerals economic concentrations of this magmatic arc.

LOCAL GEOLOGY In the magmatic arc, the most important and best known mineralizations are hosted by the arc-type Mara Rosa (northwestern Goiás) and Bom Jardim (western Goiás) volcanicsedimentary sequences. In the Mara Rosa area, the volcanicsedimentary sequence, which hosts the Posse and Zacarias deposits, was divided by Arantes et al. (1991 a,b) into three main belts referred to as the Eastern (tuffs of intermediate composition, felsic volcanic rocks, greywacke and metachert), Central (basalt, graphitic shale, iron formations, and minor feldspathic sandstone and felsic volcanics) and Western (mafic and ultramafic volcanics, felsic volcanics, greywacke, iron formation and metachert) NNE-trending belts. The sequence was intruded by granite and gabbro plutons. The authors point out that these lithotypes underwent regional metamorphism ranging from upper greenschist to upper amphibolite facies, and that the Brasiliano Orogeny resulted in the development of isoclinal folds and regional $\mathrm{N} 20^{\circ}-40^{\circ} \mathrm{E}$ trending shear zones with $\mathrm{N} 50^{\circ}-70^{\circ} \mathrm{E}$ trending ancillary shear splays. Palermo (1996) proposes that the amphibolites of the Mara Rosa region are dominantly arc-type calc-alkaline metabasalts. Kuyumjian $(1994,1995,1989)$ observes that throughout the Chapada (Alto Horizonte) area (situated approximately $40 \mathrm{~km}$ to the south of the Mara Rosa town), the Eastern Belt, which hosts the Chapada deposit, consists of a variety of metamorphic rocks. These are metagraywackes, sillimanite-staurolite-kyanite bearing schist, quartzfeldspathic biotite schist, feldspathic metasandstone, garnet-biotite schist, metachert, banded iron formation, calc-silicate rocks and exhalites, with intercalations of calc-alkaline quartz amphibolite and quartz-garnet amphibolite. The Central Belt includes pillowed tholeiitic diopside amphibolite, epidote amphibolite and garnet amphibolite, with minor intercalations of banded iron formation and metachert. In the Western Belt, the rocks are staurolite-kyanite-garnet bearing schist, calc-silicate rocks and feldspathic biotite gneiss. The sequence is intruded by tonalites, granodiorites and gabbros. Zircon U$\mathrm{Pb}$ ages of $862 \pm 8 \mathrm{Ma}$ and $856 \pm 13 /-7 \mathrm{Ma}$ from felsic metavolcanic rock and metatonalite from Mara Rosa region, respectively, were obtained by Pimentel et al. (1993) and interpreted by the authors to represent the time of deposition of the rocks. All lithologies in the Chapada area were affected by metamorphism ranging from greenschist-epidote amphibolite to upper amphibolite facies. Post-metamorphic barren pegmatites, quartz veins and diabase dykes crosscut these rocks. The volcanic-sedimentary sequence was affected by a pervasive regional foliation that trends NE and dips to NW and that was overprinted during the Brasiliano orogeny, and is associated with recumbent isoclinal, open and normal folds. Younger crosscutting foliations generate crenulations. Shear zones display NS, N10 $0^{\circ}-20^{\circ} \mathrm{W}$ and $\mathrm{N} 20^{\circ}-$ $40^{\circ} \mathrm{Ed}$ trends. Brasiliano deformation places the Mara Rosa volcanicsedimentary sequence in the hangingwall of the Rio dos Bois thrust fault, whose footwall consists of Paleoproterozoic Santa Terezinha volcanic-sedimentary sequence that occurs to the east (Kuyumjian 1995). This fault has a dextral oblique and reverse sense of shear (Kuyumjian et al. 2000). The geochemical characteristics of the amphibolites and associated plutonic rocks within the Mara Rosa volcanic-sedimentary sequence indicate an oceanic island arc-back-arc tectonic setting (Kuyumjian and Suddaby 1988, Kuyumjian 1989 a,b, Pimentel et al. 1999). The Bom Jardim de Goiás Volcanic-Sedimentary Complex (Fragomeni and Costa 1976) or Bom Jardim de Goiás Group (Seer 1985) is a NNE-SSW $15 \mathrm{~km}$ long and $5 \mathrm{~km}$ wide sequence exposed approximately $30 \mathrm{~km}$ to the southeast of the township of Bom Jardim de Goiás. According to Seer and Nilson (1985) the stratigraphy of this group comprises the following units, from bottom to top: basalt, rhyolite, andesites, andesitic tuff, basic pyroclastic rocks, chert, polymictic conglomerate, orthoconglomerate, subarkose, greywacke, phyllite and siltite, all metamorphosed to the greenschist facies. The metabasalts from the sequence are tholeiitic, and the meta-andesites and metarhyolites are calc-alkaline, formed in an island arc-type setting. The volcanic-sedimentary sequence was intruded by postBrasiliano granite magmatism (Serra Negra Granite) dated ca. $508 \mathrm{Ma}$ (Pimentel et al. 1999). The sequence was affected by four phases of deformation, generating isoclinal folds, open folds, mylonitization related to transcurrent faults, and several phases of fracturing and gravity faults. Main structural directions are EW, N $40^{\circ}-60^{\circ} \mathrm{W}, \mathrm{N} 10^{\circ}$ $20^{\circ} \mathrm{E}, \mathrm{N} 40^{\circ}-70^{\circ} \mathrm{E}$ and NS.

\section{ORE DEPOSIT FEATURES The Chapada copper-gold}

deposit The Chapada $\mathrm{Cu}-\mathrm{Au}$ deposit is located $8 \mathrm{~km}$ southwest of the town of Alto Horizonte (Chapada), within the Eastern Belt. It is hosted by a sequence comprising feldspathic quartzites, quartzofeldspathic biotite schist (dacitic metatuff protolith?), biotitemicrocline bearing gneiss (felsic metavolcanic protolith?), amphibolite of calc-alkaline affinity, and hydrothermal alteration products such as epidote-rich rock (epidosite), pyrite-magnetite-quartz-sericite schist, gedrite-anthophilyte schist, kyanite schist and minor staurolite-kyanite ortho-amphibolite (Kuyumjian 1991,1995). The deposit is controlled by a $20^{\circ}-40^{\circ} \mathrm{E}$ trending shear zone, but subsidiary $\mathrm{N} 20^{\circ}-40^{\circ} \mathrm{W}, \mathrm{N} 50^{\circ}-$ $70^{\circ} \mathrm{E}, \mathrm{N} 10^{\circ} \mathrm{E}$ and NS trending shear systems are also present. According to Oliveira et al. (1997) NS trending transcurrent shear zones played an important role in the evolution of the gold mineralizations in the region. The ore zone coincides with the structural trends of major NE-trending axes and W-dipping limbs of isoclinal fold. This isoclinal fold zone is refolded into open folds. The ore zone is $1.5 \mathrm{~km}$ long, $0.5 \mathrm{~km}$ wide and $80 \mathrm{~m}$ thick, and contains $134.10^{6}$ metric tons of ore with $0.44 \% \mathrm{Cu}$ and $0.35 \mathrm{~g} / \mathrm{t} \mathrm{Au}$ (Silva and Sá 1988). The ore body consists of pyrite-chalcopyrite-magnetite disseminated in feldspathic biotite schist, but also in sericite-rich schist and silicified zone. The ore mineralogy also includes hematite, bornite, chalcocite, sphalerite, galena, pyrrhotite and molybdenite (Richardson et al. 1986, Kuyumjian 1995). Gold is very fine-grained, included in chalcopyrite, and less commonly occurs as coarse-grained gold, in 


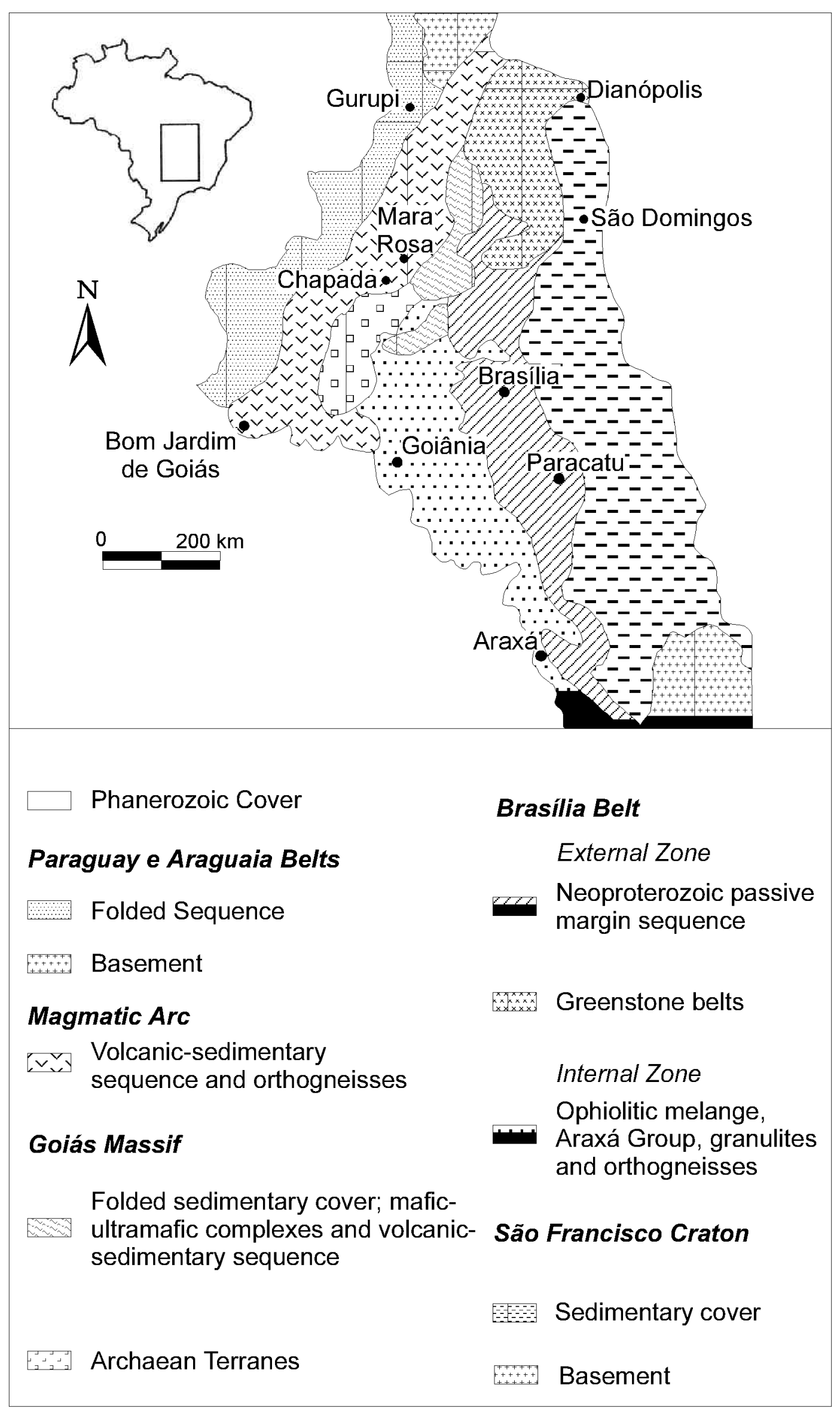


between sulphide grains. The sulphide minerals are frequently elongated, bent and boudinaged together with mica, and also occur as inclusions in metamorphic minerals, which indicate the sin- or premetamorphic nature of the Chapada mineralization.

The Posse gold deposit The deposit is located within the Eastern Belt approximately $5 \mathrm{~km}$ north or the town of Mara Rosa. According to Arantes et al. (1991a,b) the primary mineralization occurs in a series of NE-trending subparallel lenses that can be traced upon a cut off grade of $1 \mathrm{~g} / \mathrm{t}$ and strike $35^{\circ}-45^{\circ} \mathrm{SW}$ over $1 \mathrm{~km}$ and dip about $50^{0} \mathrm{NW}$. The ore body contains $1.7 \mathrm{Mt}$ at $2.24 \mathrm{~g} / \mathrm{t}$ Au to a depth of $60 \mathrm{~m}$. The mineralization is dominantly conformable with the stratigraphy and is associated with hydrothermal alteration characterized by a silicified core with pyrite that tends to host the bulk of the higher gold grades, enveloped by an epidote-pyrite-sericite zone. Sericite, pyrite, sillimanite, kyanite, chlorite, and fuchsite also occur as product of hydrothermal alteration of the footwall mafic volcanic rocks. Gold occurs as free gold, intergrown with frohbergite, or filling the silicate grain boundaries. Palermo (1999) evidenced tellurides of gold, silver, lead and bismuth, and also observed that chalcopyrite and pyrrhotite are included in the ore paragenesis. There are evidences that structure played an important role in emplacing the mineralization.

The Zacarias gold-silver-barite deposit The deposit (650.000 tons at $4.4 \mathrm{~g} / \mathrm{t} \mathrm{Au}, 48 \mathrm{~g} / \mathrm{t} \mathrm{Ag}$, and $10 \%$ baryte) is situated 11 $\mathrm{km}$ westward of the township of Mara Rosa, within the Central Belt of the Mara Rosa sequence. According to Arantes et al. (1991 a,b), the hangingwall sequence of the deposit consists of feldspathic sandstone, pyritic black shale horizon, chert, andesitic tuff and felsic tuff, whereas the footwall sequence is composed of basaltic-andesitic tuff and lesser felsic tuff. The ore horizon occurs in quartz lode, which can be subdivided into an upper Ba-rich chert and a lower Ba-poor, oellacherite-rich zone. The mineralization consists of free gold, silver and barite and minor zinc, lead and copper. The bulk of the preciousbase metal mineralization is hosted by the upper Ba-rich portion of the lode and consists of pyrite, sphalerite, galena and chalcopyrite and traces of tetrahedrite/bournonite. Magnetite is the principal oxide accessory mineral. Page (1990) identified gold in grain boundaries, as inclusions and in fracture fillings, and silver mainly sited in electrum.

The Bom Jardim copper-gold deposit The major ore bodies $\left(4.6 \times 10^{6}\right.$ tons at $0.92 \% \mathrm{Cu}$ and $\left.0.9 \mathrm{ppm} \mathrm{Au}\right)$ are confined to an approximately 700-meter long and 200-meter wide NNW-SSE trending zone within hydrothermally altered rhyodacitic metatuff of the sequence (Costa et al. 1979). Seer (1985) defined the main ore as a NS-trending tabular zone hosted by silicified andesitic metatuffs with intercalated metachert (Córrego da Aldeia Formation). Mineralizations occur as veinlets of actinolite, quartz, carbonate, chalcopyrite, pyrite, hematite and magnetite, which were probably originated from exhalative fluids, and segregations of chlorite, carbonates, quartz, sericite, biotite and very fine grained opaque minerals along $\mathrm{N} 10^{\circ} \mathrm{W}$, EW and $\mathrm{N}^{\circ} 0^{\circ}-50^{\circ} \mathrm{W}$ fold axis and within cataclastic zones related to transcurrent faults. Costa et al. (1979) describe massive sulphide veins of about 1.0 meter thick, associated with brecciated material crosscutting the orebody. The ore mineralogy includes pyrite, chalcopyrite, covelline, magnetite, pyrrhotite, hematite, rutile, sphalerite, gold, quartz, actinolite, chlorite, carbonate, biotite and epidote. Gold occurs as very small inclusions in pyrite.

Ore genesis Most of the studies carried out to the present on the Goiás magmatic arc mineral deposits have suggested porphyry
(Chapada deposit) and volcanogenic hydrothermal exhalative (Chapada, Posse, Zacarias and Bom Jardim deposits) systems at the time of the main metals deposition. Based mainly on $\mathrm{S}$ isotope composition of pyrite and chalcopyrite, Richardson et al. (1986) proposed a wall-rock porphyry copper model for the origin of the Chapada deposit. Very close to this deposit, the epidote-rich zone extends regionally towards north and south, Kuyumjian $(1991,1995)$ identified narrow bands of pale yellow green rock (epidosite) consisting of epidote and sphene. This epidosite was interpreted as representing reaction zones of major ore-forming volcanogenic hydrothermal exhalative solutions. According to Kuyumjian (1995) the initial genetic stage involved reactions between heated seawater and basalts in the Mara Rosa sequence, leaching and precipitating metals. Subsequently, magmatic hydrothermal fluid accompanied small dioritic intrusions that were late but co-magmatic in the volcanicsedimentary sequence evolution. This fluid leached metals from favorable source rocks and penetrated the earlier mineralized hydrothermal zone. Finally, metamorphogenic fluids, generated during the Brasiliano Orogeny, formed gold- enriched quartz veins (Sorongo and Filó gold mineralizations).

According to Arantes et al. (1991 a,b) the Posse deposit is considered to be epigenetic, superimposed on a preexisting alteration (pyritic, phyllic and propylitic) zones, in contrast to the syngenetic model proposed by Angeiras et al. (1988). Palermo (1999) proposed that the Posse gold mineralization is epigenetic, post-regional metamorphism, hosted by alkaline orthogneiss (metamorphosed Atype granite) intercalated in the volcanic-sedimentary sequence and hydrothermally altered during the late thrust tectonic event in the region. These orthogneisses have been considered as felsic metavolcanics by Arantes et al. (1991 a,b) in the Mara Rosa area and Kuyumjian $(1994,1995)$ in the Chapada area.

Arantes et al. (1991 a,b) favor a syngenetic origin for the Zacarias deposit (VMS-type) and Poll (1990) suggests that it may have been formed within a sea floor caldera located within a back-arc basin. In relation to the Bom Jardim deposit, Seer (1985) favors a volcanogenic exhalative origin, followed by metamorphogenic redistribution of the ore-forming minerals.

Some of the characteristics of the above mentioned mineralizations fit well with epithermal systems: i) convergent tectonic metabasalts and granitoids; ii) calc-alkaline metavolcanics and calc-alkaline to alkaline granitoids; iii) silicic, phyllic and propylitic alteration (e.g. the Posse mineralization consistent with either subaqueous or subaerial arc systems) perhaps indicating a metamorphosed volcanic-hosted epithermal system; iv) a probable metamorphosed version of the island-arc porphyry-epithermal deposits (the Chapada deposit); v) a probable epithermal silification (the Bom Jardim deposit); vi) highlevel porphyry deep-epithermal system copper-gold mineral assemblage (Bom Jardim deposit). Although these informations are not suggestive of specific type of mineralization, I speculate that, at least the Chapada, Posse and Bom Jardim de Goiás deposits may represent metamorphosed porphyry-epithermal systems related mineralizations.

FINAL REMARKS There are many gaps in our knowledge of the geological history of the magmatic arc of western Goiás. Detailed studies of the economically significant deposits have yet to be done. Mining activities in the magmatic arc terrane have been restricted to its central and southeastern portions. Large areas of this geotectonic unit, with several mineral occurrences, are promising exploration targets for porphyry-epithermal (?) and volcanogenic hydrothermal exhalative systems-related deposits.

\section{References}

Angeiras A.G., Costa L.A.M. da, Santos R.C. dos. 1988. Depósito de ouro de Mara Rosa, Goiás. In: DNPM/CVRD, C.Schobbenhaus C.E.S.Coelho (ed.), Principais depósiGoiás. In: DNPM/C
tos minerais do Brasil, 3:523-534.

Arantes D., Osborne G.A., Buck P.S. 1991a. The Mara Rosa volcanic-sedimentary sequence and associated gold mineralization. In: Brazil Gold'91, Belo Horizonte, MG, Procceedings, 221-229.

Arantes D., Buck P.S., Osborne G.A., Porto C.G. 1991b. A sequência vulcano-sedimenta de Mara Rosa e mineralizações associadas. Boletim Informativo, SBG-Núcleo Centro-Oeste, 14:27-40.
Araújo Filho J. O. de and Kuyumjian R.M. 1996. Regional distribution and structural control of the gold occurrences/deposits in the Goiás massif and Brasília belt. Rev. Bras. Geociências., 25(2):109-112.

Costa S.A.G., Fragomeni P.R.P., Campos E.C., Almeida W.J. 1979. Projeto Bom Jardim Relatório Final de Pesquisa para Cu-Pb-Zn no município Bom Jardim de Goiás. CPRM-SUREG/Goiânia, 3 vol..

Fragomeni P.R. P. \& Costa S.A.G. 1976. Complexo Vulcano-Sedimentar de Bom Jardim de Goiás - Base do Grupo Cuiabá. In: Congr. Bras. Geologia, 29, Ouro Preto,MG, Resumos, Boletim 1:p.11. 
Fuck R.A. 1994. A Faixa Brasília e a compartimentação tectônica na Província Tocantins. In: SBG-Núcleo de Brasília, Simp. Geol. Centro-Oeste, 4, Brasília, Anais, 184-187.

Kuyumjian R.M. and Suddaby P. 1988. Chapada amphibolites: do they represent metamorphosed back-arc maginal basin volcanics? In: Intern. Conf. Geochim. Evol. Contin. Crust., Poços de Caldas, MG., Abstracts: 222-228.

Kuyumjian R.M. 1989. The geochemistry and tectonic significance of amphibolites from the Chapada sequence, central Brazil. University of London, England, $\mathrm{Ph} . \mathrm{D}$. Thesis, $289 \mathrm{p}$

Kuyumjian R.M. 1989. Geoquímica e significado do posicionamento geotectônico de rochas plutônicas da região de Chapada, Goiás, Brasil. In: SBGq, Congr. Bras. Geoquímica,

Kuyumjian R.M. 1991. A suggested hydrothermal exhalative origin for the Chapada coppergold deposit, Brazil. In: Brazil Gold'91, Belo Horizonte, MG, Procceedings, 231-

Kuyumjian R.M. 1994. A sequência Mara Rosa na região de Chapada, Goiás. Boletim Geociências Centro-Oeste (SBG), 34-38.

Kuyumjian R.M. 1995. Diversity of fluids in the origin of the Chapada $\mathrm{Cu}-\mathrm{Au}$ deposit, Goiás. Rev. Bras. Geociências, 25(3): 203-205.

Kuyumjian R.M., Campos J.E.G., Oliveira C.G. de, Queiroz C.L. 2000. Registros de evolução transamazônica na Província Estrutural do Tocantins: exemplo da região de Campinorte-Alto Horizonte, Goiás. Rev. Bras. Geociências (in press).

Oliveira C.G., Sintia A.V., Barbosa I.O. 1997. Influência da deformação transcorrente-NS na mineralização aurífera na sequência vulcano-sedimentar de Mara Rosa. In: SBG, Simp. Geol Centro-Oeste, 6, Cuiabá,MT Anais:59-61.

Page M.L. 1990. Zacarias mineralogy-Drill-Hole MRD 48: Western Mining Corporation, internal memorandum.

Palermo N. 1996. Identicação de três séries magmáticas na região de Mara Rosa, Goiás. In: SBG, Congr. Bras. Geol., 34, Ouro Preto, MG, Anais, 2:219-222.

Palermo N. 1999. A mineralização aurífera de Posse na região de Mara Rosa, Goiás. In SBG, Núcleo Brasília/Núcleo Centro-Oeste/Núcleo Minas Gerais, Simp. Geol. Centro-Oeste, 7/ Simp. Geol. Minas Gerais, 10, Resumos Expandidos, 33.

Pimentel M.M., Fuck R., Machado N., Fuck R.F., Ribeiro K.R., Viana M.G. 1993. Dado geocronológicos U-Pb preliminares na região Mara Rosa, Goiás: implicações para a época de mineralização de Au e para a evolução tectonica Neoproterozóica no Centro-Oeste. In: SBGq, Congr. Bras. Geoq., 4, Brasília, Anais, 255-258.
Pimentel M.M., Whitehouse M.J., Viana M.G., Fuck A.A., Machado N. 1997. The Mara Rosa Arc in the Tocantins Province: further evidence for Neoproterozoic crusta accretion in Central Brazil. Precamb.Res., 81:299-310.

Pimentel M.M., Fuck R.A., Yunges S. 1998. New Sm-Nd isotopic constraints for the age of metamorphic events in the Neoproterozoic Brasília Belt, Central Brazil. In: International Conference Basement Tectonics, Ouro Preto,MG, Abstracts, 50-52.

Pimentel M.M., Fuck R., Botelho N.F. 1999. Granites and the geodynamic history of the neoproterozoic Brasília belt, Central Brazil: a review. Lithos, 28:463-483.

Poll N.J. 1994. The geology of the Zacarias gold-silver-barite deposit, Goiás State, Brazil. Colorado School of Mines,USA. M. Sc. Thesis, $124 \mathrm{p}$.

Richardson S.V., Kesler S.I., Essene E.J. 1986. Origin and geochemistry of the Chapada CuAu deposit, Goiás, Brazil: a metamorphosed wall-rock porphyry copper deposit. Econ. Geol., 81:1884-1898.

Richardson S.V., Jones M.L., Kesler S.E. 1988. Strontium isotopic geochemistry of PanAfrican/Brasiliano rocks, Chapada copper deposit, Goiás, Brazil. Geol. Rundschau, 77(3):763-770.

Seer J.H. 1985. Geologia, deformação e mineralização de cobre no Complexo VulcanoSedimentar de Bom Jardim de Goiás. Instituto de Geociências, Universidade de Brasília, Brasília, DF, Dissertação de Mestrado, 181p.

Seer J.H. \& Nilson A.A. 1985. Contribuição à geologia das unidades pré-cambrianas da região de Bom Jardim de Goiás. In: SBG/Núcleo Centro-Oeste, Simp. Geol. CentroOeste, 2, Goiânia, Ata:267-281.

Silva J.A. and Sá J.A.G. 1988. Jazida de cobre de Chapada, Mara Rosa, Goiás. In: DNPM/ CVRD, C.Schobbenhaus, C.E.S.Coelho (ed.) Principais depósitos minerais do Brasil, 3, 55-60.
Contribution IGC-168
Received March 8, 2000 Accepted for publication May 15, 2000 